\title{
KONSEP PROFESI PERAN GURU
}

\author{
Muhammad Maulana \\ Email: 2010128210006@mhs.ulm.ac.id \\ Program Studi Pendidikan IPS Fakultas Keguruan dan Ilmu Pendidikan \\ Universitas Lambung Mangkurat \\ Banjarmasin
}

\begin{abstract}
Abstrak
Profesi guru memiliki peran penting dalam pendidikan pada proses yang khususnya dalam bidang jabatan atau pekerjaan yang menuntut keahlian, yang bahwa dapat melalui pendidikan dan latihan tertentu, untuk menuntut persyaratan khusus yang memiliki tanggung jawab dan kode etika tertentu. Sebuah keprofesian berperilaku yang harus sesuai normanorma yang di bolehkan dan menghindari dan ditetapkan oleh organisasi atau asosiasi oleh kode etika dalam profesi yang selama ini dijalankan tugas profesi masing-masing. Profesi guru tidak dapat dipegang sama sembarang orang yang di karenakan guru sebagai panutan yang paling banyak bergaul dalam dengan peserta didik, dalam tahapan bahwasanya profesi guru memerlukan persiapan melalui pendidikan dan pelatihan secara khusu pada professional yang memiliki suatu jabatan yang memerlukan dan pelatihan secara khusus dalam mendidik peserta didik. Berdasarkan aturan undang-undang pendidik di atur oleh UU No. 14 Tahun 2005 yang mengatur tentang guru dan dosen.
\end{abstract}

\section{PENDAHULUAN}

Konsep profesi mengandung inti dari suatu jabatan atau pekerjaan yang memiliki ke ahlian dalam bidangnya. yang di mana profesi sebagai wadah suatu pekerjaan yang sangat tidak bisa di lakukan oleh sembarang orang yang belum memiliki pendidikan yang terlatih dan tidak di siapkan secara khusus, untuk melakukan sebuah pekerjaan yang seseorang dapat di katakan professional yang mempunyai makna ke ahlian dengan pengetahuan yang di miliki dalam bidang- bidang profesi untuk melayani pekerjaannya (Hasanah, A. 2012: 6). Di dalam tugas profesi harus memiliki rasa tanggung jawab nya yang di atas kan oleh keputusannya baik secara pemikiran maupun sikap, dan juga harus memiliki kesamaan menjunjung dalam etika profesi seperti di dalam organisasi yang harus menyesuaikan tugas personal yang mencerminkan suatu kepribadian dari seorang professional.

Profesi guru sebagai seorang pengajar (pendidik) yang merupakan tokoh panutan yang paling banyak berinterakasi untuk bisa bergaul dengan para peserta didik di bidang lembaga pendidikan. Guru di katakan sebagai profesi karena memiliki wadah dalam 
pekerjaan yang disebut dengan jabatan ke ahlian dalam bidangnya sendiri untuk melaksanakan proses pembelajaran, untuk kewajiban dalam mengembangkan ke aktifan yang dimana dapat membantu melaksanakan berbagai program belajar, terutama sebagai upaya untuk memaksimal kualitas dalam menggerakan dan mendorong semangat peserta didik untuk menguasai dalam mengikuti pelajaran dalam bidang ilmu yang di berikan oleh guru. Di dalam Profesi guru harus adanya kata akademisi dalam peranan seorang guru yang dapat di katakan sebagai guru yang profesional.

\section{PERAN GURU SEBAGAI SEBUAH PROFESI}

Guru dapat golongkan sebagai profesi di nyatakan secara umum guru memiliki jabatan khusus yang professional dalam melaksanakan proses pembelajaran yang tidak dapat di lakukan sembarangan orang di luar bidang pendidikan, menilai serta membimbing peserta didik dalam meraih ke suksesan dan memiliki budi pekerti. Seorang guru dalam melaksanakan tugas profesi nya harus memiliki spesialisasi ilmu dalam setiap profesi untuk membangun berdasarkan kekhususan dalam profesi ke ilmuan nya. Sehingga orang yang masuk dalam bidang profesi haruslah memiliki latar belakang pendidikan yang memiliki jabatan dari suatu pekerjaan itu sendiri (Susanto, 2020: 12). Dalam mengerjakan peran profesinya guru secara baik yang secara umum guru harus memiliki perilaku dan kemampuan yang memadai untuk perkembangan peserta didik nya dalam kode etik menjalankan tugas profesinya secara baik dalam menguasai berbagai hal yang berhubungan dengan professional nya dalam pembelajaran baik secara khusus atau umum.

Menurut noor jamaluddin (1978: 1) guru adalah pendidik, yaitu orang dewasa yang bertanggung jawab memberi bimbingan atau bantuan kepada anak didik dalam perkembangan jasmani dan rohaninya agar mencapai kedewasaannya, mampu berdiri sendiri dapat melaksanakan tugasnya sebagai makhluk allah khalifah di muka bumi sebagai makluk sosial dan individu yang sanggup berdiri sendiri (Susanto, 2020: 16).

Pada dasarnya di dalam profesi keguruan memiliki peran, hak, dan kewajiban nya oleh seorang guru yang di atur dalam undang- undang yang menjamin peran, hak, dan kewajiban guru sebagai pendidik yang di atur dalam peraturan undang- undang yang berkaitan dengan pendidikan. Dalam UU No. 14 Tahun 2005 tentang guru dan dosen, serta menurut para ahli sebagai berikut:

- Memperoleh penghasilan di atas kebutuhan hidup minimum dan jaminan kesejahteraan sosial.

- Mendapatkan promosi dan penghargaan sesuai dengan tugas dan prestasi kerja.

- Memperoleh perlindungan dalam melaksanakan tugas dan hak atas kekayaan intelektual.

- Memperoleh kesempatan untuk meningkatkan kompetensi. 
- Memperoleh dan memanfaatkan sarana dan prasarana pembelajaran untuk menunjang kelancaran tugas keprofesionalan.

- Memiliki kebebasan dalam memberikan penilaian dan ikut menentukan kelulusan, penghargaan, dan atau sanksi kepada peserta didik sesuai dengan kaidah pendidikan, kode etik guru, dan peraturan perundang-undangan.

- Memperoleh rasa aman dan jaminan keselamatan dalam melaksanakan tugas.

- Memiliki kebebasan untuk berserikat dalam organisasi profesi.

- Memiliki kesempatan untuk berperan dalam penentuan kebijakan pendidikan.

- Memperoleh kesempatan untuk mengembangkan dan meningkatkan kualifikasi akademik dan kompetensi.

- Memperoleh pelatihan dan pengembangan profesi dalam bidangnya.

\section{GURU INDONESIA DAN TANTANGAN PROFESIONALISME}

Profesionalisme suatu perkejaan yang pada dasarnya mempunyai makna bermutu dan berkualitas dalam menggambarkan sejumlah persyaaratan yang harus dimiliki seorang guru di indonesia yang akan memangku pada pekerjaannya untuk memajukan pendidikan Indonesia yang pada nantinya akan mendukung terjadinya peningkatan kualitas pendidikan di Indonesia itu sendiri. dalam membina kemutuan dan kualitas guru dalam tantang profesionalisme tidak dapat hanyar di pandang sebelah mata saja atau di anggap remeh lagi dalam peran ke unggulannya untuk di perlukan nya memajukan pendidikan di Indonesia. (Hasanah, A. 2012: 2) Dengan adanya perwujudan dalam profesionalisme dari seorang guru dimana sikap dan perilaku yang disentaiasa kan dapat mengubah untuk memotivasi membantu pendidikan di Indonesia dan membawa peserta didik dalam mencapai tujuan pendidikan yang hendaknya di tentukan dan syarat besar atas keberhasilan atau kegagalan dalam pengajaran proses pembelajaran yang sangat beperan penting dalam untuk memajukan pendidikan Indonesia.

Dalam tuntutan sebagai guru profesional atau mempunyai profesinalisme dalam untuk menerapkan komponen untu pelaksana teknis pendidikan untuk berupaya maksimal dalam mendidik peserta didik secara professional dengan sistem pembelajaran yang tepat dalam proses sasaran untuk mencapai kompentensi yang mencakup dalam empat komponen kompetensi yakini mencakup dari Kompentensi professional guru, Kompentensi pedagogik guru, Kompetensi sosial guru, Kompetensi kepribadian guru. Yang dimana kompentensi professional merupakan kemampuan yang dimiliki oleh guru, menurut pandangan ahli tentang kompentensi professional guru yang di kutip dari (Susanto, 2020: 63), Menurut cooper (1984: 15) terbagi ke dalam 4 komponen kompetensi dasar, yakni :

A. Mempunyai pengetahuan tentang belajar dan tingkah laku manusia.

B. Mempunayai pengetahuan dan menguasai bidang studi yang di binanya.

C. Mempunyai sikap yang tepat tentang diri sendiri, sekolah, teman sejawat dan bidang studi yang di binanya. 
D. Mempunyai keterampilan dalam teknik mengajar.

\section{SIMPULAN}

Konsep profesi mengandung inti dari suatu jabatan atau pekerjaan yang memiliki ke ahlian dalam bidangnya. yang di mana profesi sebagai wadah suatu pekerjaan yang sangat tidak bisa di lakukan oleh sembarang orang yang belum memiliki pendidikan yang terlatih dan tidak di siapkan secara khusus, untuk melakukan sebuah pekerjaan yang seseorang dapat di katakan professional yang mempunyai makna ke ahlian dengan pengetahuan yang di miliki dalam bidang- bidang profesi untuk melayani pekerjaannya. Profesi guru sebagai seorang pengajar (pendidik) yang merupakan tokoh panutan yang paling banyak berinterakasi untuk bisa bergaul dengan para peserta didik di bidang lembaga pendidikan. guru memiliki jabatan khusus yang professional dalam melaksanakan proses pembelajaran yang tidak dapat di lakukan sembarangan orang di luar bidang pendidikan, menilai serta membimbing peserta didik dalam meraih ke suksesan dan memiliki budi pekerti. Profesi guru memerlukan persiapan melalui pendidikan dan pelatihan secara khusus pada professional yang memiliki suatu jabatan yang memerlukan dan pelatihan secara khusus dalam mendidik peserta didik. Berdasarkan aturan undang-undang pendidik di atur oleh UU No. 14 Tahun 2005 yang mengatur tentang guru dan dosen.

Profesionalisme suatu perkejaan yang pada dasarnya mempunyai makna bermutu dan berkualitas dalam menggambarkan sejumlah persyaaratan yang harus dimiliki seorang guru di indonesia yang akan memangku pada pekerjaannya untuk memajukan pendidikan Indonesia yang pada nantinya akan mendukung terjadinya peningkatan kualitas pendidikan di Indonesia itu sendiri. menerapkan komponen untu pelaksana teknis pendidikan untuk berupaya maksimal dalam mendidik peserta didik secara professional dengan sistem pembelajaran yang tepat dalam proses sasaran untuk mencapai kompentensi yang mencakup dalam empat komponen kompetensi yakini mencakup dari Kompentensi professional guru, Kompentensi pedagogik guru, Kompetensi sosial guru, Kompetensi kepribadian guru.

\section{REFERENSI}

Efendi, I., Prawitasari, M., \& Susanto, H. (2021). Implementasi Penilaian Pembelajaran Pada Kurikulum 2013 Mata Pelajaran Sejarah. Prabayaksa: Journal of History Education, 1(1), 21-25.

Susanto, H. (2020). Profesi Keguruan. Banjarmasin: FKIP Universitas Lambung Mangkurat.

Susanto, H., \& Akmal, H. (2018). Efektivitas Penggunaan Aplikasi Pembelajaran Berbasis Mobile Smartphone Sebagai Media Pengenalan Sejarah Lokal Masa Revolusi Fisik Di Kalimantan Selatan Pada Siswa Sekolah Menengah Atas. HISTORIA: Jurnal Program Studi Pendidikan Sejarah, 6(2), 197-206. 
Susanto, H., Irmawati, I., Akmal, H., \& Abbas, E. W. (2021). Media Film Dokumenter Masuknya Islam Ke Nusantara dan Pengaruhnya Terhadap Keterampilan Berpikir Kritis Siswa. HISTORIA: Jurnal Program Studi Pendidikan Sejarah, 9(1).

Syaharuddin, S., \& Susanto, H. (2019). Sejarah Pendidikan Indonesia (Era Pra Kolonialisme Nusantara sampai Reformasi). Banjarmasin: FKIP Universitas Lambung Mangkurat.

Hasanah, A. (2012). Pengembangan profesi guru.

Danumiharja, M. (2014). Profesi Tenaga Kependidikan. Deepublish. 